\title{
Research on Technology Innovation Efficiency of China's Manufacturing Industry: an Empirical Analysis Based on Domestic Enterprises
}

\author{
Danqing Li \\ Wuhan Donghu University, Economic Department, Wuhan 430212, China
}

Keywords: Manufacturing industry, Technology innovation efficiency, Stochastic frontier analysis (SFA).

\begin{abstract}
Based on the approach of Stochastic Frontier Analysis and adopting the model of Trans-long Production Function, using the panel data of 25 manufacturing industries from 2009 to 2015 in China, this paper measures the technology innovation efficiency of China's manufacturing industry. We find that from 2009 to 2015, the real technology innovation efficiency is only $60 \%$ to $70 \%$ of the maximum possible level of technology innovation efficiency.
\end{abstract}

\section{Introduction}

In recent years, China's manufacturing technology innovation resources continue growing, research and development funds investment of 965 billion yuan in 2015 [1], research and development personnel in full-time equivalent to nearly 2.5 million per year. However, resources are limited; R\&D resources in China are still relatively scarce at present, so it is very important to improve the efficiency of R\&D input and output. This paper argues that, although in recent years R\&D investment continuously increased in manufacturing, the technology content of products has not been effectively promoted and international competitiveness of manufacturing is still insufficient. In this context, it is of great realistic significance to study the efficiency of Chinese manufacturing technology innovation.

The existing research on technology innovation efficiency is relatively few. In the existing literature, scholars mostly study on a certain area of the manufacturing industry, such as Guo Bing(2014)[2] , Chen Wei etc.(2017)[3]; or a sub industry of the manufacturing industry, such as Niu Zengdong(2012)[4], Xia Haili etc.(2016)[5]. Compared with the existing literature, this paper develops the following two sides: on the one side, in the choice of samples, this paper is based on the national level rather than the regional level, with all sectors of the manufacturing industry rather than a sub industry. On the other side, because the main body of manufacturing is domestic enterprise, this article focuses on the domestic enterprises.

\section{Model Building and Variables Selection}

Due to the change of the statistical caliber of past statistical yearbooks, this article selects the domestic enterprises in the manufacturing of 25 two yards of industry to research; the related data comes from China Statistical Yearbook, China Industry Statistical Yearbook and China Science and Technology Yearbook, etc.

Model Building. This paper uses the stochastic frontier analysis method (SFA) (Aigner,1997) [6] to analyze the technology innovation efficiency of different industries in manufacturing. The general form of stochastic frontier analysis method is:

$$
y_{i t}=f\left(x_{i t}, \beta\right) \exp \left(v_{i t}-u_{i t}\right)
$$

In the Eq. (1), y represents output variables, $x$ represents input variables, i represents different industries in manufacturing, $\mathrm{t}$ represents time, $\beta$ represents parameters to be estimated, $\left(v_{i t}-u_{i t}\right)$ 
represents composite disturbance, $v_{i t}$ and $u_{i t}$ are independent of each other. $v_{i t}$ represents random error term; it is random and an uncontrolled factor, used to calculate the system inefficiency; ${ }_{i t}$ is technical error term, and can be controlled, used to calculate the technical inefficiency.

Technology innovation efficiency of manufacturing industries means the ratio of the real technology innovation output level and the largest possible technology innovation output level after controlling the random impact factors. The expression of technology innovation efficiency $T E_{i t}$ is as below:

$$
T E_{i t}=\frac{y_{i t}}{f\left(x_{i t}, \beta\right) \exp \left(v_{i t}\right)}=\frac{f\left(x_{i t}, \beta\right) \exp \left(v_{i t}\right) \exp \left(-u_{i t}\right)}{f\left(x_{i t}, \beta\right) \exp \left(v_{i t}\right)}=\exp \left(-u_{i t}\right)
$$

In the Eq.(2), when $u_{i t}>0, T E_{i t}<1$, indicating that there are technical efficiency in the production activity in the manufacturing industries.

This paper uses trans-log production function of stochastic frontier approach:

$$
\ln Y_{i t}=\beta_{0}+\beta_{1} \ln R D_{i t}+\beta_{2} \ln R D P_{i t}+\frac{1}{2} \beta_{3}\left(\ln R D_{i t}\right)^{2}+\frac{1}{2} \beta_{4}\left(\ln R D P_{i t}\right)^{2}+\beta_{5} \ln R D_{i t} \ln R D P_{i t}+V_{i t}-U_{i t}
$$

In the Eq. (3), Y, RD and RDP respectively new products' sales income, R\&D capital investment and $R \& D$ personnel investment. i represents different industries and t represents different years. $\beta_{0}$ is constant term and $\beta$ is vector to be estimated. $V_{i t}-U_{i t}$ represents stochastic error term of the model, supposing it submitting to truncated normal distribution $\mathrm{N}\left(M_{i t}, \sigma_{U}^{2}\right) . e^{-M_{i t}}$ represents the R\&D activities of technical efficiency of industry $i$ in the period t. The greater $M_{i t}$, the lower the technical innovation efficiency, indicating less research output from equal R\&D investment.

Variables Selection. The most basic elements of innovative activities include the capital investment and labor input. Existing literature generally used "R\&D funds" when measured capital investment and used $R \& D$ staff full-time equivalent to measure labor input in the process of innovation.

This paper uses new product sales income to measure technology innovation output Y. While using the index of new product sales income, it comprehensively considers the innovation of the enterprise and its value realization. To the index of new product sales income, it uses Producer price index (PPI) as deflator (the base year is 2009).

When to calculate R\&D capital investment, this paper uses perpetual inventory method, and the calculation formula is as follows:

$$
R D_{i t}=(1-\delta) R D_{i(t-1)}+E_{i t}
$$

In Eq. (4), $R D_{i t}$ represents $R \& D$ capital inventory of the industry $\mathrm{i}$ in the year $\mathrm{t}$ after dealing with the deflator; while $E_{i t}$ represents R\&D capital input of the industry $\mathrm{i}$ in the year $\mathrm{t} ; \delta$ is the rate of depreciation. This paper uses "above designated size industrial enterprises R\&D expenses" to estimate the R\&D capital inventory. Using 2009 as base year, it assumes that the growth rate of R\&D capital is equal to the rate of growth of $E$. The initial value of $R \& D$ is $R D_{i 0}=\frac{E_{i 0}}{(g+\delta)}$, and $g$ is the average annual growth rate of $E$. The depreciation rate of R\&D capital is set to $15 \%$.

In the case of building R\&D price index, according to the National Bureau of Statistics and Ministry of Science and Technology, the spending on labor cost and equipment cost is basically the same in 2009-2015. In view of this, the fixed asset investment price index and the consumer price index give the same weighting to 0.5 , and $R \& D$ price index $(\mathrm{PI})$ is the average of the two, that is, 


$$
P I=(F+C) / 2
$$

In Eq.(5), $\mathrm{F}$ is the fixed asset investment price index and $\mathrm{C}$ is the consumer price index.

The total amount of equivalent (human year) of $R \& D$ personnel is used to measure $R \& D$ personnel (RDP) investment.

\section{Empirical Analysis Results}

Based on above research, through software Frontier 4.1, we get the efficiency of technological innovation in various industries of domestic enterprises in manufacturing, see Table 1.

Table 1 Technology Innovation Efficiency of Domestic Enterprise in Manufacturing

\begin{tabular}{|c|c|c|c|c|c|c|c|c|}
\hline Item & 2009 & 2010 & 2011 & 2012 & 2013 & 2014 & 2015 & Average \\
\hline $\begin{array}{l}\text { Processing of Food from } \\
\text { Agricultural Products }\end{array}$ & 0.793 & 0.782 & 0.770 & 0.758 & 0.745 & 0.754 & 0.749 & 0.764 \\
\hline Manufacture of Foods & 0.626 & 0.608 & 0.589 & 0.570 & 0.551 & 0.569 & 0.554 & 0.581 \\
\hline Manufacture of Beverage & 0.631 & 0.613 & 0.595 & 0.576 & 0.556 & 0.563 & 0.567 & 0.586 \\
\hline Manufacture of Textile & 0.915 & 0.910 & 0.904 & 0.899 & 0.893 & 0.895 & 0.894 & 0.901 \\
\hline $\begin{array}{l}\text { Manufacture of Textile } \\
\text { Wearing, Apparel, } \\
\text { Footwear and Caps }\end{array}$ & 0.927 & 0.923 & 0.918 & 0.913 & 0.908 & 0.903 & 0.905 & 0.914 \\
\hline $\begin{array}{l}\text { Manufacture of Leather, } \\
\text { Fur, Feather and Its } \\
\text { Products }\end{array}$ & 0.875 & 0.868 & 0.860 & 0.852 & 0.844 & 0.839 & 0.856 & 0.856 \\
\hline $\begin{array}{l}\text { Processing of Timber, } \\
\text { Manufacture of Wood, } \\
\text { Bamboo, Rattan, Palm and } \\
\text { Straw Products }\end{array}$ & 0.802 & 0.791 & 0.780 & 0.768 & 0.755 & 0.756 & 0.772 & 0.775 \\
\hline Manufacture of Furniture & 0.771 & 0.759 & 0.746 & 0.733 & 0.719 & 0.717 & 0.726 & 0.739 \\
\hline $\begin{array}{l}\text { Manufacture of Paper and } \\
\text { Paper Products }\end{array}$ & 0.761 & 0.748 & 0.735 & 0.721 & 0.707 & 0.709 & 0.706 & 0.727 \\
\hline $\begin{array}{l}\text { Printing, Reproduction of } \\
\text { Recording Media }\end{array}$ & 0.663 & 0.646 & 0.629 & 0.611 & 0.593 & 0.608 & 0.612 & 0.623 \\
\hline $\begin{array}{l}\text { Manufacture of Articles } \\
\text { for Culture, Education and } \\
\text { Sport Activities }\end{array}$ & 0.624 & 0.606 & 0.587 & 0.568 & 0.548 & 0.569 & 0.571 & 0.582 \\
\hline $\begin{array}{l}\text { Processing of Petroleum, } \\
\text { Coking and Processing of } \\
\text { Nuclear Fuel }\end{array}$ & 0.821 & 0.811 & 0.800 & 0.790 & 0.778 & 0.780 & 0.783 & 0.795 \\
\hline $\begin{array}{l}\text { Manufacture of Raw } \\
\text { Chemical Materials and } \\
\text { Chemical Products }\end{array}$ & 0.677 & 0.660 & 0.644 & 0.626 & 0.608 & 0.601 & 0.619 & 0.634 \\
\hline Manufacture of Medicines & 0.562 & 0.542 & 0.522 & 0.501 & 0.479 & 0.503 & 0.524 & 0.519 \\
\hline $\begin{array}{l}\text { Manufacture of Chemical } \\
\text { Fibres }\end{array}$ & 0.741 & 0.727 & 0.713 & 0.698 & 0.683 & 0.694 & 0.703 & 0.709 \\
\hline $\begin{array}{l}\text { Manufacture of Rubber } \\
\text { and Plastics }\end{array}$ & 0.737 & 0.723 & 0.709 & 0.694 & 0.678 & 0.680 & 0.701 & 0.703 \\
\hline $\begin{array}{l}\text { Manufacture of } \\
\text { Non-metallic Mineral } \\
\text { Products }\end{array}$ & 0.586 & 0.567 & 0.547 & 0.527 & 0.506 & 0.518 & 0.540 & 0.541 \\
\hline $\begin{array}{l}\text { Smelting and Pressing of } \\
\text { Ferrous Metals }\end{array}$ & 0.725 & 0.710 & 0.695 & 0.680 & 0.664 & 0.671 & 0.683 & 0.690 \\
\hline
\end{tabular}




\begin{tabular}{|c|c|c|c|c|c|c|c|c|}
\hline $\begin{array}{l}\text { Smelting and Pressing of } \\
\text { Non-ferrous Metals }\end{array}$ & 0.839 & 0.830 & 0.821 & 0.811 & 0.800 & 0.812 & 0.824 & 0.820 \\
\hline $\begin{array}{l}\text { Manufacture of Metal } \\
\text { Products }\end{array}$ & 0.699 & 0.683 & 0.667 & 0.651 & 0.633 & 0.644 & 0.652 & 0.661 \\
\hline $\begin{array}{l}\text { Manufacture of General } \\
\text { Purpose Machinery }\end{array}$ & 0.621 & 0.603 & 0.584 & 0.564 & 0.545 & 0.553 & 0.577 & 0.578 \\
\hline $\begin{array}{l}\text { Manufacture of Special } \\
\text { Purpose Machinery }\end{array}$ & 0.576 & 0.557 & 0.537 & 0.516 & 0.495 & 0.510 & 0.539 & 0.533 \\
\hline $\begin{array}{l}\text { Manufacture of Transport } \\
\text { Equipment }\end{array}$ & 0.937 & 0.933 & 0.929 & 0.925 & 0.920 & 0.927 & 0.922 & 0.927 \\
\hline $\begin{array}{l}\text { Manufacture of Electrical } \\
\text { Machinery and Equipment }\end{array}$ & 0.927 & 0.923 & 0.918 & 0.913 & 0.908 & 0.915 & 0.910 & 0.916 \\
\hline $\begin{array}{l}\text { Manufacture of } \\
\text { Communication } \\
\text { Equipment, Computers } \\
\text { and Other Electronic } \\
\text { Equipment }\end{array}$ & 0.500 & 0.479 & 0.457 & 0.435 & 0.413 & 0.421 & 0.430 & 0.448 \\
\hline Average Value & 0.733 & 0.720 & 0.706 & 0.692 & 0.677 & 0.684 & 0.693 & 0.701 \\
\hline
\end{tabular}

Data source: relevant years Chinese Industry Statistics Yearbook, China Science and Technology Statistics Yearbook.

Table 1 shows the mean of manufacturing technology innovation in domestic enterprises has declined steadily from 2009 to 2015, then it went up slowly. Among the 25 manufacturing industries, some industries' technology innovation efficiency values are very low, only slightly greater than 0.5, these industries include manufacture of medicines, manufacture of special purpose machinery, manufacture of non-metallic mineral products and so on. In contrast, technology innovation efficiency higher industries include textile industry, textile and clothing industry, electrical machinery and equipment manufacturing and transportation equipment manufacturing industry, these industries’ technology innovation efficiency values are above 0.9

\section{Conclusions}

Based on the stochastic frontier analysis method, this paper measures the technology innovation efficiency of domestic enterprises in manufacturing. We conclude that from 2009 to 2015, there is technology inefficiency in domestic enterprises in manufacturing industry. On the whole, the real technology innovation efficiency is only $60 \%$ to $70 \%$ of the maximum possible level of technology innovation efficiency.

\section{Acknowledgements}

This paper is sponsored by Youth Foudation WuHan Donghu University (2017dhsk004).

\section{References}

[1] Information on http://www.stats.gov.cn/tjsj/zxfb/201611/t20161111_1427139.html.

[2] Bing G. Study on the measurement and optimization of the efficiency in scientific and technology investment of the low-and medium-technology manufacturing [J], Science of Science and Management of S.\&T., 2014, 35(05): 64-70.

[3] Wei C. Technical innovation efficiency evaluation of large and medium industrial enterprises in northeast China: based on the DEA-Malmquist method [J], East China Economic Management, 2017(02): 66-71.

[4] Zengdong N, Qianxiao Z. An analysis of technology innovation efficiency of manufacturing equipment industries in China [J], Quantitative \& Technical Economics, 2012(11): 51-67.

[5] Haili X. Research on the efficiency of equipment manufacturing technology and its influencing 
factors [J], Science \& Technology Progress and Policy, 2016(03):65-70.

[6] Aigner D. J., Lovell C.A.K., Schmidt P., Formulation and Estimation of Stochastic Frontier Production Function Models [J], Journal of Econometrics, 1977(6):21-37. 